This is a revised personal version of the text of the final journal article, which is made available for scholarly purposes only, in accordance with the journal's author permissions. The full citation is:

Tampio, E., Ervasti, S., Paavola, T., Heaven, S., Banks, C., \& Rintala, J. (2014). Anaerobic digestion of autoclaved and untreated food waste. Waste Management, 34(2), 370-377.

DOI: 10.1016/i.wasman.2013.10.024 


\section{Anaerobic digestion of autoclaved and untreated food waste}

2 Elina Tampio ${ }^{\mathrm{a}, *}$, Satu Ervasti ${ }^{\mathrm{a}}$, Teija Paavola ${ }^{\mathrm{a}, 1}$, Sonia Heaven ${ }^{\mathrm{b}}$, Charles Banks ${ }^{\mathrm{b}}$, Jukka

3 Rintala ${ }^{a, 2}$

$4 \quad{ }^{a}$ Bioenergy and Environment, MTT Agrifood Research Finland, FI-31600 Jokioinen,

$5 \quad$ Finland

$6{ }^{b}$ University of Southampton, Faculty of Engineering and the Environment, Southampton

$7 \quad S O 171 B J, U K$

\section{Abstract}

9 Anaerobic digestion of autoclaved $\left(160^{\circ} \mathrm{C}, 6.2 \mathrm{bar}\right)$ and untreated source segregated

10 food waste (FW) was compared over 473 days in semi-continuously fed mesophilic

11 reactors with trace elements supplementation, at organic loading rates (OLRs) of 2, 3, 4

12 and $6 \mathrm{kgVolatile}$ solids(VS)/ $\mathrm{m}^{3} \mathrm{~d}$. Methane yields at all OLR were 5-10\% higher for

13 untreated FW (maximum $0.483 \pm 0.013 \mathrm{~m}^{3} \mathrm{CH}_{4} / \mathrm{kgVS}$ at $3 \mathrm{kgVS} / \mathrm{m}^{3} \mathrm{~d}$ ) than autoclaved

14 FW (maximum $0.439 \pm 0.020 \mathrm{~m}^{3} \mathrm{CH}_{4} / \mathrm{kgVS}$ at $4 \mathrm{kgVS} / \mathrm{m}^{3} \mathrm{~d}$ ). The residual methane

15 potential of both digestates at all OLRs was less than $0.110 \mathrm{~m}^{3} \mathrm{CH}_{4} / \mathrm{kgVS}$, indicating

16 efficient methanation in all cases. Use of acclimated inoculum allowed very rapid

17 increases in OLR. Reactors fed on autoclaved FW showed lower ammonium and

18 hydrogen sulphide concentrations, probably due to reduced protein hydrolysis as a

19 result of formation of Maillard compounds. In the current study this reduced

\footnotetext{
${ }^{*}$ Corresponding author. Tel.: +358 29531 7800, E-mail address: elina.tampio@mtt.fi

${ }^{1}$ Present address: Biovakka Suomi Ltd, Autokatu 8, FI-20380 Turku, Finland

2 Present address: Department of Chemistry and Bioengineering, Tampere University of Technology, FI33101 Tampere, Finland.
} 
20 biodegradability appears to outweigh any benefit due to thermal hydrolysis of ligno-

21 cellulosic components.

\section{Keywords}

23 Food waste, anaerobic digestion, autoclave treatment, organic loading rate, nitrogen

\section{Introduction}

Anaerobic digestion is an efficient technique for the treatment of source segregated biodegradable municipal wastes, e.g. biowastes and food waste (FW), as it recovers energy in the form of biogas for use in combined heat and power (CHP) plants, in vehicles and for grid injection; and also allows recycling of nutrients through application of digestion residues in crop production. Both the Renewable Energy

31 directive (2009/28/EC, EU 2009) and the Landfill directive (99/31/EC, EU 1999) have been strong drivers in promoting the use of anaerobic digestion for this application in recent years.

Although co-digestion of FW with sewage sludge and animal manures has been common practice, treatment of FW alone has often proved difficult (Banks et al. 2008, Neiva Correia et al. 2008, Zhang et al. 2012). These difficulties have been attributed to ammonia inhibition resulting from a high protein content (Gallert et al. 1998), and are often indicated by accumulation of volatile fatty acids (VFA) (Banks et al. 2012). To achieve stable anaerobic digestion with FW alone, organic loading rates (OLR) are

40 usually maintained at low values: $2.25 \mathrm{kgVS} / \mathrm{m}^{3} \mathrm{~d}$ at a hydraulic retention time (HRT) of

4180 days in Banks et al. (2011) and from 1-4 kgVS/m³ (HRT 14-30 days) as reported in 
42 Cecchi et al. (2003). VFA accumulation at higher OLR has recently been linked to trace element (TE) deficiencies (Banks et al. 2012). When supplemented with TE successful FW digestion has been reported at OLRs of $5 \mathrm{kgVS} / \mathrm{m}^{3} \mathrm{~d}$ (Banks et al. 2012) and 6.64 $\mathrm{kgVS} / \mathrm{m}^{3} \mathrm{~d}$ (Zhang and Jahng 2012).

Thermal and hydrothermal pre-treatments have been widely studied as a means of hydrolysing recalcitrant components in a wide range of wastes to make them easier to degrade (Papadimitriou 2010, Ren et al. 2006, Takashima and Tanaka 2008); these techniques have also been used as pre-treatments before anaerobic digestion of mixed biowastes (Lissens et al. 2004, Sawayama et al. 1997). One such hydrothermal treatment is autoclaving, where water is used as a reagent at increased temperature and pressure, to hydrolyse and solubilise sugars, starch, proteins and hemicellulose (Papadimitriou 2010, Ren et al. 2006). Materials pre-treated by autoclaving under various conditions have shown increased methane production in batch tests: digested swine slurry autoclaved at $120{ }^{\circ} \mathrm{C}$ showed an increase in $\mathrm{CH}_{4}$ yield of $115 \%$ (Menardo et al. 2011) and autoclaving of mixed kitchen garbage $\left(175^{\circ} \mathrm{C}, 40\right.$ bar, 1 hour $)$ increased $\mathrm{CH}_{4}$ yield by $30 \%$ (Sawayama et al. 1997). Improved methane production has also been observed in continuously-stirred tank reactors (CSTRs) treating waste activated sludge (WAS), with $12 \%$ and $25 \%$ increases after autoclaving at $135{ }^{\circ} \mathrm{C}$ and

$60190{ }^{\circ} \mathrm{C}$, respectively (Bougrier et al. 2007). In contrast, more aggressive thermal and hydrothermal pre-treatments at higher temperatures (around $180^{\circ} \mathrm{C}$ ) have been reported to decrease biodegradability and biogas production during anaerobic digestion of WAS and sewage sludge (Bougrier et al. 2008, Pinnekamp 1989). This is believed to be related to the formation of complex and inhibitory Maillard compounds, produced by reactions between amino acids and 
66 carbohydrates (Bougrier et al. 2008, Takashima and Tanaka 2008). Maillard compounds

67 start to form at temperatures above $100{ }^{\circ} \mathrm{C}$ depending on the retention time (Müller

68 2001, Nursten 2005), while the formation of more complex compounds, such as

69 acrylamides and other vinylogous compounds, increases at higher temperatures $\left(180{ }^{\circ} \mathrm{C}\right.$,

$70 \quad$ Stadler et al. 2004).

The aim of this study was to evaluate the anaerobic digestion of untreated and autoclaved $\left(160{ }^{\circ} \mathrm{C}, 6.2\right.$ bar) $\mathrm{FW}$ at a range of different OLRs $(2,3,4$ and 6

$\mathrm{kgVS} / \mathrm{m}^{3}$ day) in semi-continuously fed intermittently-stirred mesophilic reactors. The biochemical methane potential (BMP) of the feedstocks and the residual methane potential (RMP) of the digestates were also assessed in batch assays.

\section{Materials and methods}

\subsection{Origin and characterization of FW and inocula}

The source segregated domestic FW used in the study was collected from the

South Shropshire Biowaste digestion plant in Ludlow, UK. Biodegradable bags used for waste collection were removed and the FW material was mixed and divided into two equal portions. One portion was pre-treated at $160{ }^{\circ} \mathrm{C}$ and 6.2 bars in a novel doubleauger autoclave (AeroThermal Group Ltd, UK) that provides improved mixing and steam penetration; the other portion was left untreated. Both portions were then passed through a macerating grinder (S52/010 Waste Disposer, IMC Limited, UK), packed into 35-litre plastic boxes ( 7 untreated and 8 autoclaved), frozen and shipped at $-20{ }^{\circ} \mathrm{C}$ to MTT Agrifood Research, Finland. amounts required for weekly feeding of the digesters, and these smaller portions were 
again stored at $-20{ }^{\circ} \mathrm{C}$. Each week portions of the autoclaved and untreated $\mathrm{FW}$ were thawed and stored at $4{ }^{\circ} \mathrm{C}$ and used as daily feed. The $\mathrm{pH}$, total solids (TS), volatile solids (VS), ammonium nitrogen $\left(\mathrm{NH}_{4}-\mathrm{N}\right)$, total Kjeldahl nitrogen $(\mathrm{TKN})$, soluble chemical oxygen demand (SCOD) and VFA content was determined for each new box

93 of feed.

The reactors were inoculated with digestate from a mesophilic CSTR digesting mechanically dewatered sewage sludge (Biovakka Suomi Ltd, Turku, Finland) (Table 1). In the BMP assays inoculum was taken from an anaerobic digester treating municipal and industrial biowastes (Envor Biotech Ltd, Forssa, Finland).

\subsection{Semi-continuous trials}

Four 11-litre stainless steel stirred tank reactors (STRs) (Metener Ltd, Finland)

100 were operated at $37^{\circ} \mathrm{C}$. Stirring ( $32 \mathrm{rpm}$ ) was semi-continuous with 5 seconds on and

10160 seconds off. The reactors were fed manually five times a week through an inlet tube

102 which extended below the digestate surface, and which was also used for digestate sampling. Digestate overflowed from the reactors by gravity through a u-tube trap to prevent gas escape. Between days 1-195 hourly gas volume and methane content were measured using an automatic system in which the produced biogas was collected into a

106 small ( $220 \mathrm{ml})$ gas storage vessel on top of the reactor. From day 195 onwards, due to

107 break down of the automated system, gas volume was measured by water displacement

108 in a volume-calibrated cylindrical gas collector, after which the gas was collected in

109 aluminium gas bags.

110 Reactors were fed with untreated FW (R1) and autoclaved FW (R3). After 18

111 days acclimation period with reduced feeding the experiments started at an OLR of 2 
$112 \mathrm{kgVS} / \mathrm{m}^{3}$ day, corresponding to HRT of 117 and 94 days for R1 and R3 respectively. On

113 day 151, after 1.1 (R1) and 1.4 (R3) HRTs, the OLR was raised to $3 \mathrm{kgVS} / \mathrm{m}^{3}$ day and

114 after $1.3(\mathrm{R} 1)$ and 1.7 (R3) HRTs to $4 \mathrm{kgVS} / \mathrm{m}^{3}$ day on day 256 (HRT $78 \mathrm{~d}$ and $58 \mathrm{~d}$ for

115 untreated, $63 \mathrm{~d}$ and $47 \mathrm{~d}$ for autoclaved FW, respectively).

116 On day 327 parallel reactors fed on untreated (R2) and autoclaved FW (R4) were

117 started at an OLR of $3 \mathrm{kgVS} / \mathrm{m}^{3}$ day, using 5.7 litres of digestate from R1 and R3

118 respectively as inoculum. After 2.8 and 3.4 HRTs in reactors R1 and R3 and 1.2 and 1.4

119 HRTs in reactors R2 and R4, the OLR in all four reactors was further increased to 6

$120 \mathrm{kgVS} / \mathrm{m}^{3}$ day on day 418 , with a corresponding decrease in HRT to $39 \mathrm{~d}$ and $31 \mathrm{~d}$ in the

121 untreated and autoclaved FW reactors. Most of the data presented below are taken from

122 reactors R1 and R3 due to the longer running period. During days 179-193 reactors R1

123 and R3 were once a week supplemented with $11 \mathrm{ml}$ of a trace element (TE) solution

124 containing Se $(0.2 \mathrm{mg} / \mathrm{l})$ and Co $(1.0 \mathrm{mg} / \mathrm{l})$. From day 199 onwards all reactors were

125 given a weekly supplement of two TE solutions, one containing cation elements $(\mathrm{mg} / \mathrm{l})$ :

$126 \mathrm{Al} \mathrm{0.1,} \mathrm{B} \mathrm{0.1,} \mathrm{Co} \mathrm{1.0,} \mathrm{Cu} \mathrm{0.1,} \mathrm{Fe} \mathrm{5.0,} \mathrm{Mn} \mathrm{1.0,} \mathrm{Ni} \mathrm{1.0,} \mathrm{Zn} \mathrm{0.2;} \mathrm{and} \mathrm{the} \mathrm{other} \mathrm{oxyanions}$

127 (mg/l): Mo 0.2, Se 0.2 and W 0.2 (Banks et al. 2012). $1 \mathrm{ml}$ of each of these TE solutions

128 was added for each $\mathrm{kg}$ of digestate removed from the reactors over the one-week period.

129 Grab samples of digestate (about $250 \mathrm{~g}$ ) were taken every two weeks for analysis

130 of TS, VS, SCOD, $\mathrm{NH}_{4}-\mathrm{N}, \mathrm{TKN}$, and samples for VFA analysis (about $50 \mathrm{~g}$ ) were taken

131 once a week. Digestate $\mathrm{pH}$ was measured weekly. Larger volumes of digestate were

132 collected on days 130 (2 1), 214 (1 1), 287 (1 1) and 321 (1 1). After removal of these

133 larger samples, daily feeding of the reactors was adjusted to compensate for the reduced

134 volume until the normal operating level was restored. 


\subsection{Biochemical and residual methane potential assays}

BMP and RMP assays were performed at $37^{\circ} \mathrm{C}$ using automated testing

137 equipment (Bioprocess Control Ltd, Sweden). The assays were mixed mechanically (84

$138 \mathrm{rpm}$ ) for one minute per hour. Carbon dioxide was absorbed by $\mathrm{NaOH}$ before the

139 automated gas volume measurement, which was based on liquid displacement. Assays

140 were conducted in duplicate or triplicate, each with a total liquid volume of $400 \mathrm{ml}$

141 (BMP) or $200 \mathrm{ml}$ (RMP assays). The inoculum to substrate ratio in BMP assays was 1:1

142 on a VS basis. $\mathrm{NaHCO}_{3}(3 \mathrm{~g} / \mathrm{l})$ was used as a buffer and if the $\mathrm{pH}$ was lower than 7.5 it

143 was adjusted to around 8 with $3 \mathrm{M} \mathrm{NaOH}$. In RMP assays digestates from the STR

144 reactors were incubated without inoculum. The results are given as average values of

145 the triplicate or duplicate assays.

\section{2.4. Analyses and calculations}

147 TS and VS were determined according to SFS 3008 (Finnish Standard

148 Association 1990) and $\mathrm{NH}_{4}-\mathrm{N}$ according to McCullough (1967). TKN was analysed by

149 a standard method (AOAC 1990) using a Foss Kjeltec 2400 Analyzer Unit (Foss

150 Tecator AB, Höganäs, Sweden), with $\mathrm{Cu}$ as a catalyst. For soluble COD analysis FW

151 samples were diluted 1:10 with distilled water, and agitated for 1 hour. Diluted FW and

152 raw digestate samples were centrifuged $(2493 \times \mathrm{g}, 15 \mathrm{~min})$ after which the supernatant

153 was further centrifuged $(16168 \times \mathrm{g}, 10 \mathrm{~min})$ and stored in a freezer, then thawed before

154 analysis according to SFS 5504 (Finnish Standards Association 2002). pH was

155 determined using a VWR pH100 pH-analyzer (VWR International). Iron concentration

156 was analysed according to Luh Huang and Schulte (1985) using inductively coupled 
157 plasma emission spectrometry (ICP-OES) (Thermo Jarrel Ash Iris Advantage, Franklin, 158 USA).

159 Samples for VFA analysis were centrifuged $(1831 \times \mathrm{g}, 10 \mathrm{~min})$ and filtered with

160 Chromafil GF/PET-20/25 filters. Concentrations of acetic, propionic, iso-butyric, n-

161 butyric, iso-valeric, valeric and caproic acids were determined using a HP 6890 gas

162 chromatograph with an HP 7683 autosampler (Hewlett-Packard, Little Falls, USA) and

163 GC ChemStation Rev. B.03.02 software. The GC was fitted with a $10 \mathrm{~m} \times 0.53 \mathrm{~mm} \times 1$

$164 \mu \mathrm{m}$ HP-FFAP capillary column (Agilent Technologies, USA) and a flame ionisation

165 detector with helium as a carrier gas $(9 \mathrm{ml} / \mathrm{min})$. Oven temperatures were $60-78{ }^{\circ} \mathrm{C}(25$

$\left.166{ }^{\circ} \mathrm{C} / \mathrm{min}\right)$, isothermal $1 \mathrm{~min}, 150{ }^{\circ} \mathrm{C}\left(7.5^{\circ} \mathrm{C} / \mathrm{min}\right)$ and $25^{\circ} \mathrm{C} / \mathrm{min}$ to $180{ }^{\circ} \mathrm{C}$ with $3 \mathrm{~min}$

167 final time. The injector and detector temperatures were $220{ }^{\circ} \mathrm{C}$ and $280{ }^{\circ} \mathrm{C}$,

168 respectively.

169 From day 1 to 195 methane composition was determined automatically during

170 emptying of the gas storage vessel by infrared analysis (ExTox Gasmess-Systeme

$171 \mathrm{GmbH}$, Germany). From day 195 to 314, gas composition was analysed using a portable

172 Combimass GA-m gas analyzer (Binder Engineering GmbH, Germany), and during

173 days 315-446 the infrared measuring equipment was used.

174 The reactor was fed for 5 days a week, but the OLR in $\mathrm{kgVS} / \mathrm{m}^{3}$ day is expressed

175 as the average daily weight of substrate fed to the reactor over a one-week period. HRT

176 was calculated based on feedstock densities. All biogas and methane yields were

177 converted to STP conditions $\left(0^{\circ} \mathrm{C}, 100 \mathrm{kPa}\right)$ according to the ideal gas law. Methane

178 yields in the RMP assays were calculated in two ways; by dividing the cumulative

179 methane production by the 1) VS of the added digestate and 2) by the VS of the feed of 
180 the semi-continuous reactors at the time of digestate sampling. The latter enables direct 181 comparison of the methane yield in the RMP with that in the reactors. Free ammonia

$182\left(\mathrm{NH}_{3}-\mathrm{N}\right)$ concentrations were calculated according to Anthonisen et al. (1976):

$$
\mathrm{NH}_{3}-\mathrm{N}=\left(\mathrm{NH}_{4}-\mathrm{N} \times 10^{\mathrm{pH}}\right) /\left(\left(\mathrm{K}_{\mathrm{b}} / \mathrm{K}_{\mathrm{w}}\right)+10^{\mathrm{pH}}\right),
$$

184 where $\mathrm{K}_{\mathrm{b}}$ is the ammonia ionisation constant and $\mathrm{K}_{\mathrm{w}}$ the ionisation constant of water at $18537^{\circ} \mathrm{C}$.

186 3. Results and discussion

\subsection{Material characterization}

The autoclaved FW appeared much darker than the untreated FW and had a

189 pleasant caramel odour. TS and VS in the autoclaved FW were both about $15 \%$ lower

190 than in the untreated FW due to dilution by steam condensation during the autoclave

191 treatment (Table 1). TKN on fresh matter basis was lower in the autoclaved FW $(6.8 \pm$

$1920.3 \mathrm{~g} \mathrm{~N} / \mathrm{kg})$ than in untreated FW $(7.4 \pm 0.3 \mathrm{~g} \mathrm{~N} / \mathrm{kg})$. The autoclaved FW had about 22

$193 \%$ higher $\mathrm{NH}_{4}-\mathrm{N}$ and $16 \%$ higher SCOD, indicating that autoclaving had solubilised

194 some organic nitrogen and carbon components. Total VFA concentrations were lower in

195 the autoclaved material $(2.2 \pm 0.2 \mathrm{~g} / \mathrm{l})$ than in the untreated FW $(3.1 \pm 0.6 \mathrm{~g} / \mathrm{l})$

196 suggesting either that some VFA had volatilised during or after autoclaving, or that

197 some acidification of the untreated material had occurred.

199 dependent on the temperature as well as the materials used. In this study autoclaving

200 conditions of 6.2 bars and $160{ }^{\circ} \mathrm{C}$ were used. Increased concentrations of $\mathrm{NH}_{4}-\mathrm{N}$ and solubilisation of carbohydrates have previously been reported after autoclave treatment 
202 of dewatered sewage sludge $\left(175^{\circ} \mathrm{C}, 20 \mathrm{bar}\right)$, with an increase from 2.6 to $3.2 \mathrm{~g} \mathrm{NH}_{4}-$

$203 \mathrm{~N} / 1$ (Inoue et al. 1996); temperatures above $90{ }^{\circ} \mathrm{C}$ have also been reported to increase

204 ammonia concentrations from $0.35 \mathrm{gN} / 1$ to $0.7 \mathrm{gN} / 1$ in WAS (Bougrier et al. 2008).

\subsection{BMP assay}

The 35-day BMP value for untreated FW was $0.501 \pm 0.020 \mathrm{~m}^{3} \mathrm{CH}_{4} / \mathrm{kgVS}$, while that for autoclaved FW was $0.445 \pm 0.001 \mathrm{~m}^{3} \mathrm{CH}_{4} / \mathrm{kgVS}$ (Figure 1, Table 1). The lower methane yield of the autoclaved FW could be explained by Maillard reactions. Support for the occurrence of these is given by the darkening in colour of the autoclaved FW and the caramelised odour, while the increase in SCOD provides evidence of increased

211 solubilisation of carbon compounds. Similar phenomena have also been observed with

212 autoclaved WAS (Bougrier et al. 2008) and municipal solid waste (Takashima and

213 Tanaka 2008). In other studies higher methane yields have been reported after similar

214 thermal treatments (Lissens et al. 2004), but this can be attributed to the improved

215 availability of the ligno-cellulosic materials; and when these form a large proportion of

216 the waste the resulting increase may far exceed any decrease due to Maillard

217 compounds. In contrast where ligno-cellulosic content is low, as in this type of food 218 waste (Zhang et al. 2012) reductions in methane yield may result.

\section{3.3. Semi-continuous operation}

\subsubsection{Effect of loading rate on methane yields}

Process parameters from the whole experimental period (days 1-473) are shown in

222 Figure 2 and detailed results from the last four weeks of stable operation at each OLR

223 are presented in Table 2. Operation was considered stable when variations were $<0.2$

224 units in $\mathrm{pH},<90 \mathrm{mg} / \mathrm{l}$ in VFA and $<1.8 \%$ in $\mathrm{CH}_{4}$. 

for untreated FW than for autoclaved FW. The methane yields at OLR $2 \mathrm{kgVS} / \mathrm{m}^{3}$ day

227 were on average $0.443 \pm 0.038$ and $0.373 \pm 0.037 \mathrm{~m}^{3} \mathrm{CH}_{4} / \mathrm{kgVS}$ for untreated (R1) and autoclaved FW (R3), respectively. The highest yield for untreated FW was observed at OLR $3 \mathrm{kgVS} / \mathrm{m}^{3}$ day $\left(0.483 \pm 0.013 \mathrm{~m}^{3} \mathrm{CH}_{4} / \mathrm{kgVS}\right)$ while autoclaved $\mathrm{FW}$ produced the 230 highest yield at OLR $4 \mathrm{kgVS} / \mathrm{m}^{3}$ day $\left(0.439 \pm 0.020 \mathrm{~m}^{3} \mathrm{CH}_{4} / \mathrm{kgVS}\right)$. When the OLR was

231 further increased to $6 \mathrm{kgVS} / \mathrm{m}^{3}$ day methane yields decreased by $12 \%$ and $11 \%$ in untreated FW and autoclaved FW, respectively. The specific methane yield for autoclaved FW was lower at OLR $2 \mathrm{kgVS} / \mathrm{m}^{3}$ day than at higher OLRs, which could

234 possibly indicate some acclimatisation. This was not seen in the untreated FW where

235 the lowest specific methane yield occurred at OLR $6 \mathrm{kgVS} / \mathrm{m}^{3}$ day, which could indicate

236 retarded hydrolysis as no increased SCOD nor VFA was detected. At OLR 6

$237 \mathrm{kgVS} / \mathrm{m}^{3}$ day the difference in methane yields between the parallel (R2 and R4) and 238 original (R1 and $\mathrm{R} 3$ ) reactors was $<7 \%$ (Table 2 ). process to stabilise between incremental increases in OLR. Using this approach, stable

241 digestion of both autoclaved and untreated FW was achieved at the relatively high OLR 242 of $6 \mathrm{kgVS} / \mathrm{m}^{3}$ day. It was also shown, however, that when an inoculum acclimated to the 243 feedstocks was used in R2 and R4, the OLR could be rapidly increased without 244 operational disturbances such as VFA accumulation. The maximum loading rates 245 applied were similar to the $6.64 \mathrm{kgVS} / \mathrm{m}^{3}$ day achieved by Zhang and Jahng (2012) and 246 higher than the $5 \mathrm{kgVS} / \mathrm{m}^{3}$ day of Banks et al. (2012). Both of these long-term digestion 247 studies used trace elements supplementation, as did the present study. 
As far as is known, this is the first study to report anaerobic digestion of autoclaved food waste in a semi-continuously fed system. Methane yields of $0.483 \pm$ 0.013 and $0.423 \pm 0.002 \mathrm{~m}^{3} \mathrm{CH}_{4} / \mathrm{kgVS}$ for the untreated and autoclaved $\mathrm{FW}$ at OLR 3 $\mathrm{kgVS} / \mathrm{m}^{3}$ day are in good agreement with previous studies, where a full-scale digester

252 fed on the same type of source-segregated household food waste at an average OLR of $253 \quad 2.5 \mathrm{kgVS} / \mathrm{m}^{3}$ day yielded $0.402 \mathrm{~m}^{3} \mathrm{CH}_{4} / \mathrm{kgVS}$ (Banks et al. 2011). Earlier pilot-scale studies gave an average of $0.390 \mathrm{~m}^{3} \mathrm{CH}_{4} / \mathrm{kgVS}$, but using a different source of sourcesegregated domestic food waste at higher OLR (3.5 to $4 \mathrm{kgVS} / \mathrm{m}^{3}$ day), and without TE supplementation (Banks et al. 2008). Laboratory-scale FW digestion with TE supplementation was reported to yield $0.352-0.439 \mathrm{~m}^{3} \mathrm{CH}_{4} / \mathrm{kgVS}$ at an OLR of 6.64 $\mathrm{kgVS} / \mathrm{m}^{3}$ day by Zhang and Jahng (2012); while in the study by Banks et al. (2012) the methane yield for TE supplemented FW was $0.435 \mathrm{~m}^{3} \mathrm{CH}_{4} / \mathrm{kgVS}$.

The maximum methane yields for untreated and autoclaved FW in the semicontinuous trials were $0.483 \pm 0.013$ and $0.439 \pm 0.020 \mathrm{~m}^{3} \mathrm{CH}_{4} / \mathrm{kgVS}$ respectively. These were slightly lower than the BMP values in each case. The results therefore strongly indicate that even after long periods of operation no significant acclimatisation that could improve the biodegradability of compounds produced in the autoclaving process had taken place. improved degradation of ligno-cellulosic materials may outweigh any losses in

268 biodegradability as a result of formation of recalcitrant compounds during thermal 269 treatment. FW, however, has a relatively low ligno-cellulosic fibre content compared to other municipal biowaste components (e.g. garden or yard waste, paper and card), and

271 in the present study the net effect of treatment was a reduction in specific methane yield. 
272 This balance may however change with different autoclaving conditions, and in

273 particular a lowering of temperature may produce more favourable results.

274

275

276

277

278

280

281

282

283

284

285

286

287

\subsubsection{Digestion parameters}

Results for $\mathrm{pH}$, VFA, TS, VS, SCOD, $\mathrm{NH}_{4}-\mathrm{N}, \mathrm{TKN}$ are presented in Table 2 and

Figure 3. $\mathrm{pH}$ in the untreated $\mathrm{FW}$ reactor remained around 7.8 throughout the experimental period, while with autoclaved $\mathrm{FW}$ the $\mathrm{pH}$ decreased from $\mathrm{pH} 7.6$ at OLR 2 $\mathrm{kgVS} / \mathrm{m}^{3}$ day to 7.3 at OLR $6 \mathrm{kgVS} / \mathrm{m}^{3}$ day.

At an OLR of $2 \mathrm{kgVS} / \mathrm{m}^{3}$ day, total VFA concentration in both reactors remained under $250 \mathrm{mg} / \mathrm{l}$. When the OLR was increased to $3 \mathrm{kgVS} / \mathrm{m}^{3}$ day, VFA in the untreated FW reactor increased to $2400 \mathrm{mg} / \mathrm{l}$ by day 153 , and consisted mainly of acetic (about 85 $\%$ ) and propionic acids (about $10 \%$ ). In the autoclaved FW reactor VFA concentration showed smaller increases with peaks of $1500 \mathrm{mg} / \mathrm{l}$ on day 139 (consisting $98 \%$ of acetic acid) and $910 \mathrm{mg} / \mathrm{l}$ on day 160 (27\% acetic acid and $65 \%$ propionic acid). The relatively large samples (2 litres) taken from the reactors on day 130 could have contributed to these increases in VFA concentration, but similar removals of digestate at later stages in the experimental run did not have this effect. VFA concentrations reduced to under $200 \mathrm{mg} / \mathrm{l}$ in both reactors by day 214 , shortly after the introduction of trace element additions of selenium and cobalt on day 179 and full TE supplementation on day 199. This behaviour is consistent with previous reports of responses to TE supplementation where the VFA increase was linked with the loss of electron transfer interspecies during digestion (Banks et al. 2012).

TS, VS and TKN contents in both reactors gradually increased during the experimental period, with TS increasing from under 70 to over $80 \mathrm{~g} / \mathrm{kg}$. Despite the 
295 lower feedstock solids concentration, the solids content in the autoclaved FW reactor

296 was slightly higher than in the untreated FW up to the end of OLR $4 \mathrm{kgVS} / \mathrm{m}^{3}$ day. After

297 OLR was increased to $6 \mathrm{kgVS} / \mathrm{m}^{3}$ day there was an increase in solids concentrations in

298 the untreated FW reactor, which was not apparent with the autoclaved FW. The initial

299 TKN concentration in both reactors was $4.9 \mathrm{~g} \mathrm{~N} / \mathrm{kg}$ and showed a similar increase to $\sim 8$

$300 \mathrm{~g} \mathrm{~N} / \mathrm{kg}$ by around day 200 . TKN in the untreated FW reactor continued to increase until

301 around day 300 at which point it stabilised at $\sim 9 \mathrm{~g} \mathrm{~N} / \mathrm{kg}$, whereas for the autoclaved FW

302 it remained at $\sim 8 \mathrm{~g} \mathrm{~N} / \mathrm{kg}$. The differences in TKN reflected the differences in feedstock

303 concentrations. The increases in solids content were most likely associated with the

304 increase in loading, although it is possible that some accumulation was due to

305 stratification despite the intermittent mixing, as surplus digestate was discharged from

306 an overflow at the top of the reactor. Mass balance calculations affirmed, in the

307 beginning of OLR $4 \mathrm{kgVS} / \mathrm{m}^{3}$ day, that accumulation of TKN was taking place.

308 The SCOD concentration in both reactors increased from around $10 \mathrm{~g} / \mathrm{l}$ to over 20

$309 \mathrm{~g} / \mathrm{l}$ during the first 300 days of operation, then stabilised in the autoclaved FW reactor.

310 In the untreated FW reactor the SCOD increased sharply to $\sim 36 \mathrm{~g} / \mathrm{l}$ for over 50 days

311 then decreased equally sharply in the end of the run: these variations did not correspond

312 to changes in OLR and were not accomplished with changes in methane yield nor

313 digestate VFA. Total VFA concentrations accounted for only 0.5-2 \% of the SCOD. A

314 probable explanation for the general increase in SCOD in both reactors is an increase in

315 the quantity of soluble microbial products present in the digestate; this phenomenon has

316 previously been observed with solid substrates and at long retention times (Kuo et al.

317 1996, Rinćon et al. 2012). 

days from 2.4 (inoculum) to $4 \mathrm{~g} / \mathrm{kg}$ and then showed a very gradual decrease to around $3 \mathrm{~g} / \mathrm{kg}$ by the end of the experimental run. This decrease could be associated with the

322 increase in microbial biomass (Lindorfer et al. 2011) or in soluble microbial products

323 caused by the increasing OLR. In the autoclaved FW reactor, however, $\mathrm{NH}_{4}-\mathrm{N}$

324 decreased from 2.4 to about $1.2 \mathrm{~g} / \mathrm{kg}$ by the end of the experimental period. The low $325 \mathrm{NH}_{4}-\mathrm{N}$ concentrations in the autoclaved $\mathrm{FW}$ reactor were probably mainly due to the 326 effect of autoclaving and the formation of Maillard compounds from the reaction of 327 proteins with carbohydrates (Bougrier et al. 2007, 2008). Free ammonia concentrations 328 in the reactors were calculated, but $\mathrm{NH}_{3}$ remained below $0.30 \mathrm{~g} / \mathrm{kg}$ in untreated $\mathrm{FW}$ and 329 below $0.10 \mathrm{~g} / \mathrm{kg}$ in the autoclaved $\mathrm{FW}$ reactor. remained relatively stable until the OLR was raised to $6 \mathrm{kgVS} / \mathrm{m}^{3}$ day, at which point it

332 fell very slightly. In the autoclaved reactor after a slight initial rise $\mathrm{pH}$ decreased during 333 the experimental run to a final value of around 7.3. These $\mathrm{pH}$ values reflect the relative $334 \mathrm{NH}_{4}-\mathrm{N}$ concentrations in each case, as $\mathrm{NH}_{4}-\mathrm{N}$ provides buffering capacity (Procházka et 335 al. 2012). High $\mathrm{NH}_{4}-\mathrm{N}$ concentration can also inhibit the digestion process, but this is 336 greatly dependent on the feedstock materials and acclimation times (Chen et al. 2008, 337 Procházka et al. 2012). In the present study, after TE supplementation was introduced, 338 there was no evidence of the VFA accumulation that is often associated with ammonia 339 toxicity, and the free ammonia concentrations were similar to those previously observed 340 in FW digestion (Zhang et al. 2012). 
343 similar and ranged between 55-63\% during the experiment, with an average of around

$34458 \%$ (Table 2, Figure 2). It did not appear to be affected by changes in applied OLR. In 345 contrast, in a study by Zhang and Jahng (2012) on FW digestion the methane content 346 was found to decrease from $53 \%$ to $48 \%$ as the OLR was gradually increased from 3472.19 to $6.64 \mathrm{kgVS} / \mathrm{m}^{3}$ day.

Hydrogen sulphide concentration was monitored between days 166-313 while the reactors were operated at OLR 3 and $4 \mathrm{kgVS} / \mathrm{m}^{3}$ day (Figure 4). $\mathrm{H}_{2} \mathrm{~S}$ concentrations at OLR $3 \mathrm{kgVS} / \mathrm{m}^{3}$ day were $<100 \mathrm{ppm}$ in the untreated $\mathrm{FW}$ reactor and $<75 \mathrm{ppm}$ in the autoclaved FW reactor. Shortly before the OLR was increased to $4 \mathrm{kgVS} / \mathrm{m}^{3}$ day the $\mathrm{H}_{2} \mathrm{~S}$ concentration in the untreated FW reactor began to increase, and reached $480 \mathrm{ppm}$ by day 314 at which point monitoring ceased; while in the autoclaved $\mathrm{FW}$ reactor $\mathrm{H}_{2} \mathrm{~S}$ content remained $<60 \mathrm{ppm}$. $\mathrm{H}_{2} \mathrm{~S}$ was also monitored at the OLR of $6 \mathrm{kgVS} / \mathrm{m}^{3}$ day (days 448-473) and concentrations were $751 \pm 182 \mathrm{ppm}$ in the untreated FW reactors (R1 and 2) compared to $63 \pm 4 \mathrm{ppm}$ in the autoclaved FW reactors (R3, R4). the effect of autoclaving on proteins in the food waste, which may have reduced the availability of sulphur. The low $\mathrm{H}_{2} \mathrm{~S}$ concentration could also be due in part to

360 precipitation through the formation of iron sulphides. The iron content in the autoclaved

361 FW was 170 times higher than in the untreated FW (Table 1), possibly due to metal

362 contamination from the autoclaving apparatus. O'Flaherty et al. (1998) showed that sulphate-reducing bacteria $(\mathrm{SRBs})$ have an optimum $\mathrm{pH}$ slightly higher than that of methanogenic archaea, and hence the higher $\mathrm{pH}$ in the untreated $\mathrm{FW}$ reactors may have 
365 favoured the growth of SRBs causing increased $\mathrm{H}_{2} \mathrm{~S}$ concentrations. Decreasing HRT

366 will also give SRB an additional competitive advantage.

\subsection{Residual methane potential assays} operation at OLRs 2, 4 and $6 \mathrm{kgVS} / \mathrm{m}^{3}$ day (Table 3). The RMPs increased with the increasing OLRs and decreasing HRTs from $0.069 \pm 0.005 \mathrm{~m}^{3} \mathrm{CH}_{4} / \mathrm{kgVS}$ to $0.105 \pm$ $0.002 \mathrm{~m}^{3} \mathrm{CH}_{4} / \mathrm{kgVS}$ with the untreated FW and from $0.063 \pm 0.002 \mathrm{~m}^{3} \mathrm{CH}_{4} / \mathrm{kgVS}$ to $0.095 \pm 0.012 \mathrm{~m}^{3} \mathrm{CH}_{4} / \mathrm{kgVS}$ with the autoclaved FW (OLR 2 to $6 \mathrm{kgVS} / \mathrm{m}^{3} \mathrm{day}$ ). However, RMPs after operation with OLR $4 \mathrm{kgVS} / \mathrm{m}^{3}$ day were 6 and $10 \%$ lower in untreated and autoclaved FW compared to OLR $2 \mathrm{kgVS} / \mathrm{m}^{3}$ day reflecting the highest $\mathrm{CH}_{4}$ yields obtained with OLRs 3 and $4 \mathrm{kgVS} / \mathrm{m}^{3}$ day in STRs. Also few days longer storage time might have affected the RMPs after OLR $4 \mathrm{kgVS} / \mathrm{m}^{3}$ day allowing materials to slightly degrade before the RMP start. increased total methane yield of the semi-continuous reactors by $2.9-4.7 \%$ with the untreated FW and by 4.3-5.2 \% with the autoclaved FW (Table 3). The calculated total methane yield with the untreated FW was, after OLRs 2,4 and $6 \mathrm{kgVS} / \mathrm{m}^{3}$ day, 3.6-12.6

$382 \%$ lower than the BMP value $\left(0.501 \mathrm{~m}^{3} \mathrm{CH}_{4} / \mathrm{kgVS}\right)$ being closest after OLR 4

$383 \mathrm{kgVS} / \mathrm{m}^{3}$ day and thus reflecting the specific yields in STRs. Autoclaved FW showed similar STR reflecting behavior but after OLR $4 \mathrm{kgVS} / \mathrm{m}^{3}$ day the calculated total methane yield was $3.1 \%$ higher than the BMP value $\left(0.445 \mathrm{~m}^{3} \mathrm{CH}_{4} / \mathrm{kgVS}\right)$. The VS

386 removals were not cohesive with the calculated total methane yields, which could partly

387 be explained with deviations between samples. The results suggest that in both materials 
there was still a small part of biodegradable material after semi-continuous reactors and the amount increased with the increasing OLRs and decreasing HRTs.

390

\section{Conclusions}

Stable digestion of untreated and autoclaved FW was possible in TE-

392 supplemented mesophilic reactors at OLRs up to $6 \mathrm{kgVS} / \mathrm{m}^{3} \mathrm{~d}$, with yields of 0.435 and

$3930.393 \mathrm{~m}^{3} \mathrm{CH}_{4} / \mathrm{kgVS}$, respectively. Using an acclimated inoculum allowed rapid increases in OLR without process disturbance. Untreated FW showed a higher specific methane yield than autoclaved FW at all OLRs and in batch assays. This difference may

396 be due to the formation of Maillard compounds, with the resulting reduction in

397 biodegradability apparently outweighing any benefits from thermal hydrolysis of ligno-

398 cellulosic components under the autoclaving conditions used. Biogas $\mathrm{H}_{2} \mathrm{~S}$ concentrations were much lower in reactors treating autoclaved $\mathrm{FW}$.

\section{Acknowledgements}

402 (VALORGAS) project (241334). The authors are grateful to Aerothermal Group for 403 autoclaving, to BiogenGreenfinch Ltd for providing the food waste and to Biovakka 404 Suomi Ltd and Envor Biotech Ltd for providing the inoculums. We also wish to thank 405 the MTT laboratory staff for their excellent work.

\section{References}


410 Chemists, Inc., Arlington, VA. 1298 p.

411 Banks, C.J., Chessire, M., Stringfellow, A.S., 2008. A pilot-scale comparison of

412 mesophilic and thermophilic digestion of source segregated domestic food waste. Water

413 Sci. Technol. 58(7), 1475-1481.

Banks, C.J., Chesshire, M., Heaven, S., Arnold, R., 2011. Anaerobic digestion of source-segregated domestic food waste: Performance assessment by mass and energy

416 balance. Bioresour. Technol. 102, 612-620. for stable food waste digestion at elevated ammonia concentrations. Bioresour. Technol. $104,127-135$. on the semi-continuous anaerobic digestion of waste activated sludge. Biochem. Eng. J. $34,20-27$.

424 five different waste activated sludge samples solubilisation, physical properties and 425 anaerobic digestion. Chem. Eng. J. 139, 236-244.

427 Characteristics of the OFMSW and behavior of the anaerobic digestion process, in:

428 Mata-Alvarez, J. (Ed.), Biomethanization of the Organic Fraction of Municipal Solid 429 Waste. IWA Publishing, UK. pp. 141-180. 

process: A review. Bioresour. Technol. 99, 4044-4064. waste. Official Journal L 182, 16/07/1999 P. 0001-0019. of 23 April 2009 on the promotion of the use of energy from renewable sources and amending and subsequently repealing Directives 2001/77/EC and 2003/30/EC. Official Journal L 140, 05/06/2009 P. 0016-0062.

Finnish Standard Association, 1990. SFS 3008, Determination of total residue and 439 total fixed residue in water, sludge and sediment, Finnish Standard Association, 440 Helsinki, Finland. oxygen demand (CODCr) in water with closed tube method, oxidation with dichromate, 443 Finnish Standard Association, Helsinki, Finland. degradation of protein by mesophilic and thermophilic biowaste population. Appl. 446 Microbiol. Biotechnol. 50, 495-501. 
452 AD plants and effect of trace element application. Proc. International IWA Symposium on Anaerobic Digestion of Solid Wastes and Energy Crops, Vienna 28 August - 1

454 September 2011.

Thermal wet oxidation improves anaerobic biodegradability of raw and digested biowaste. Environ. Sci. Technol. 38, 3418-3424.

ICP emission spectrometry. Commun. Soil Sci. Plant Anal. 16, 943-958. colorimetric method. Clin. Chim. Acta 17, 297-304. yield. Bioresour. Technol. 102, 2026-2032. IWA International Symposium on AD of Solid Wastes and Energy Crops, Tunisia. implications. Royal Society of Chemistry, Cambridge, UK. 

growth kinetics and sulphide toxicity thresholds of a range of methanogenic, syntrophic and sulphate-reducing bacteria. Process Biochem. 33(5), 555-569. autoclaving of commingled household waste. Waste Manage. 30, 572-582. anaerobic digestion. Water Sci. Technol. 21(4-5), 97-108. of anaerobic process caused by insufficiency or excess ammonia nitrogen. Appl. Microbiol. Biotechnol. 93(1), 439-447. the nutrient ingredients of restaurant garbage. J. Environ. Sci. (China) 18(5): 10121019. whole-crop winter wheat silage for renewable energy production. Energy Fuels 26, 487 2357-2364. Bioeng. 83(5), 451-455. 
493 acrylamide and other vinylogous compounds by the Maillard reaction. J. Agric. Food 494 Chem. 52, 5550-5558.

495 Takashima, M., Tanaka, Y., 2008. Comparison of thermo-oxidative treatments for 496 the anaerobic digestion of sewage sludge. J. Chem. Technol. Biotechnol. 83, 637-642.

497 Zhang, L., Jahng, D., 2012. Long-term anaerobic digestion of food waste 498 stabilized by trace elements. Waste Manage. 32, 1509-1515.

499 Zhang Y., Banks C. J., Heaven S., 2012. Anaerobic digestion of two 500 biodegradable municipal waste streams. J. Environ. Manage. 104, 166-174. 
502 Table 1. Characteristics of untreated food waste (FW), autoclaved FW and inoculum.

\begin{tabular}{|c|c|c|c|}
\hline & Control FW & Autoclaved FW & Inoculum \\
\hline $\mathrm{pH}$ & $4.96 \pm 0.16$ & $5.01 \pm 0.12$ & N/A \\
\hline $\mathrm{TS}(\mathrm{g} / \mathrm{kg})$ & $247.5 \pm 4.7$ & $210.9 \pm 18.6$ & 77.3 \\
\hline $\mathrm{VS}(\mathrm{g} / \mathrm{kg})$ & $229.9 \pm 4.5$ & $194.6 \pm 17.6$ & 43.1 \\
\hline VS/TS (\%) & 92.9 & 92.3 & 55.8 \\
\hline $\operatorname{SCOD}(\mathrm{g} / \mathrm{l})$ & $98.2 \pm 6.5$ & $117.5 \pm 10.3$ & 11.9 \\
\hline TVFA (g/l) & $3.1 \pm 0.6$ & $2.2 \pm 0.2$ & 2.4 \\
\hline TKN (g/kg) & $7.4 \pm 0.3$ & $6.8 \pm 0.3$ & 4.9 \\
\hline $\mathrm{NH}_{4}-\mathrm{N}(\mathrm{g} / \mathrm{kg})$ & $0.32 \pm 0.12$ & $0.41 \pm 0.10$ & 2.4 \\
\hline $\mathrm{Fe}\left(\mathrm{g} / \mathrm{kg}_{\mathrm{TS}}\right)$ & $0.13 \pm 0.01$ & $22.73 \pm 12.54$ & N/A \\
\hline $\mathrm{SMP}\left(\mathrm{m}^{3} \mathrm{CH}_{4} / \mathrm{kg}_{\mathrm{VS}}\right)$ & $0.501 \pm 0.020$ & $0.445 \pm 0.001$ & N/A \\
\hline $\mathrm{SMP}\left(\mathrm{m}^{3} \mathrm{CH}_{4} / \mathrm{kg}_{\mathrm{TS}}\right)$ & $0.462 \pm 0.019$ & $0.408 \pm 0.001$ & N/A \\
\hline $\operatorname{SMP}\left(\mathrm{m}^{3} \mathrm{CH}_{4} / \mathrm{kg}_{\mathrm{FM}}\right)$ & $0.112 \pm 0.005$ & $0.084 \pm 0.0001$ & N/A \\
\hline Density $(\mathrm{kg} / \mathrm{l})$ & $1.064 \pm 0.0042$ & $1.063 \pm 0.0002$ & N/A \\
\hline
\end{tabular}

$\mathrm{N}=24$ for $\mathrm{pH}, \mathrm{N}=8$ for TS, VS, SCOD, TVFA, TKN, NH4-N, $\mathrm{N}=2$ for specific methane potentials (SMPs) and $\mathrm{Fe}, \mathrm{N}=3$ for density

N/A, not available 
Table 2. Reactor characteristics during the last 4 weeks of each organic loading rate (OLR, $\left.\mathrm{kgVS} / \mathrm{m}^{3} \mathrm{~d}\right)$ periods.

\begin{tabular}{|c|c|c|c|c|c|c|c|c|c|c|c|}
\hline OLR & Reactor & $\begin{array}{l}\text { HRT } \\
\text { (d) }\end{array}$ & $\begin{array}{c}\text { Specific } \mathrm{CH}_{4} \\
\text { yield } \\
\left(\mathrm{m}^{3} / \mathrm{kgVS}\right)\end{array}$ & TS $(\mathrm{g} / \mathrm{kg})$ & VS (g/kg) & $\begin{array}{l}\text { VS } \\
\text { removal } \\
(\%)\end{array}$ & $\mathrm{pH}$ & TVFA (mg/l) & $\begin{array}{l}\text { TKN } \\
(\mathrm{g} / \mathrm{kg})\end{array}$ & $\begin{array}{c}\mathrm{NH} 4-\mathrm{N} \\
(\mathrm{g} / \mathrm{kg})\end{array}$ & $\operatorname{SCOD}(g / l)$ \\
\hline \multirow[t]{2}{*}{2} & $\mathrm{R} 1$ & 117 & $0.443 \pm 0.038$ & $69.2 \pm 1.7$ & $44.5 \pm 0.9$ & 80.6 & $7.8 \pm 0.13$ & $267.5 \pm 53.2$ & $7.2 \pm 0.1$ & $3.8 \pm 0.14$ & $16.0 \pm 2.9$ \\
\hline & R3 & 94 & $0.373 \pm 0.037$ & $76.6 \pm 2.3$ & $55.6 \pm 1.9$ & 71.4 & $7.6 \pm 0.04$ & $132.5 \pm 17.1$ & $7.0 \pm 0.3$ & $2.1 \pm 0.06$ & $14.8 \pm 0.1$ \\
\hline \multirow[t]{4}{*}{3} & $\mathrm{R} 1$ & 78 & $0.483 \pm 0.013$ & $71.1 \pm 2.6$ & $51.4 \pm 2.5$ & 77.7 & $7.8 \pm 0.03$ & $188.0 \pm 71.9$ & $8.4 \pm 0.4$ & $4.2 \pm 0.15$ & $15.6 \pm 3.1$ \\
\hline & $\mathrm{R} 2$ & & $0.478 \pm 0.009$ & $69.8 \pm 2.2$ & $56.1 \pm 9.1$ & 75.6 & $7.8 \pm 0.08$ & $108.0 \pm 17.9$ & $8.9 \pm 0.1$ & $4.1 \pm 0.14$ & $23.0 \pm 4.3$ \\
\hline & R3 & 63 & $0.423 \pm 0.002$ & $84.0 \pm 5.3$ & $66.3 \pm 4.4$ & 65.9 & $7.5 \pm 0.02$ & $136.0 \pm 26.1$ & $8.2 \pm 0.6$ & $2.0 \pm 0.05$ & $17.6 \pm 2.3$ \\
\hline & $\mathrm{R} 4$ & & $0.433 \pm 0.009$ & $76.4 \pm 1.0$ & $63.0 \pm 1.1$ & 67.6 & $7.5 \pm 0.03$ & $92.0 \pm 23.9$ & $7.9 \pm 0.3$ & $1.7 \pm 0.03$ & $19.7 \pm 0.5$ \\
\hline \multirow[t]{2}{*}{4} & $\mathrm{R} 1$ & 58 & $0.465 \pm 0.023$ & $85.2 \pm 5.6$ & $64.2 \pm 3.7$ & 72.1 & $7.8 \pm 0.07$ & $112.0 \pm 25.9$ & $9.0 \pm 0.1$ & $3.5 \pm 0.03$ & $36.2 \pm 0.6$ \\
\hline & R3 & 47 & $0.439 \pm 0.020$ & $86.1 \pm 2.6$ & $69.9 \pm 2.7$ & 64.1 & $7.4 \pm 0.06$ & $90.0 \pm 24.5$ & $8.3 \pm 0.5$ & $1.3 \pm 0.01$ & $20.3 \pm 0.5$ \\
\hline \multirow[t]{4}{*}{6} & $\mathrm{R} 1$ & 39 & $0.405 \pm 0.006$ & $102.1 \pm 7.3$ & $72.8 \pm 4.1$ & 68.3 & $7.7 \pm 0.06$ & $165.0 \pm 42.0$ & $9.4 \pm 0.2$ & $3.2 \pm 0.08$ & $28.3 \pm 11.6$ \\
\hline & $\mathrm{R} 2$ & & $0.435 \pm 0.008$ & $90.3 \pm 2.8$ & $68.7 \pm 2.8$ & 70.1 & $7.7 \pm 0.05$ & $140.0 \pm 54.8$ & $9.4 \pm 0.1$ & $3.3 \pm 0.05$ & $25.9 \pm 10.5$ \\
\hline & $\mathrm{R} 3$ & 31 & $0.393 \pm 0.044$ & $85.7 \pm 1.7$ & $69.1 \pm 1.4$ & 64.5 & $7.2 \pm 0.05$ & $108.0 \pm 35.6$ & $7.8 \pm 0.1$ & $1.2 \pm 0.07$ & $18.2 \pm 2.0$ \\
\hline & $\mathrm{R} 4$ & & $0.383 \pm 0.013$ & $88.3 \pm 5.4$ & $72.0 \pm 3.1$ & 63.0 & $7.3 \pm 0.06$ & $110.0 \pm 21.6$ & $8.2 \pm 0.3$ & $1.2 \pm 0.13$ & $18.7 \pm 3.0$ \\
\hline
\end{tabular}

N/A, not available

$\mathrm{N}=2-5$, for $\mathrm{pH} \mathrm{N}=15$ 
Table 3. Residual methane potentials (RMPs), total methane yield and VS removals of food waste digestates after organic loading rates (OLRs, $\mathrm{kgVS} / \mathrm{m}^{3}$ day) 2, 4 and 6 in the stirred tank reactors (STRs).

\begin{tabular}{cccccc}
\hline OLR & Reactor & $\begin{array}{c}\text { RMP } \\
\left(\mathrm{m}^{3} / \mathrm{kgVS}\right)\end{array}$ & $\begin{array}{c}\mathrm{RMP}_{\text {original }} \\
\left(\mathrm{m}^{3} / \mathrm{kgVS}_{\text {feed }}\right)^{\mathrm{a}}\end{array}$ & $\begin{array}{c}\text { Total CH } \\
\text { STR+RMP } \text { yield in } \\
\left(\mathrm{m}^{3} / \mathrm{kgVS}_{\text {feed }}\right)^{\mathrm{a}}\end{array}$ & $\begin{array}{c}\text { VS removal in } \\
\text { STR+RMP }(\%)\end{array}$ \\
\hline 2 & $\mathrm{R} 1$ & $0.069 \pm 0.005$ & $0.013 \pm 0.0009$ & 0.456 & 85.1 \\
& $\mathrm{R} 3$ & $0.063 \pm 0.002$ & $0.017 \pm 0.0006$ & 0.390 & 75.3 \\
4 & $\mathrm{R} 1$ & $0.065 \pm 0.001$ & $0.017 \pm 0.0004$ & 0.482 & 80.9 \\
& $\mathrm{R} 3$ & $0.057 \pm 0.002$ & $0.020 \pm 0.0006$ & 0.459 & 67.4 \\
& $\mathrm{R} 1$ & $0.105 \pm 0.002$ & $0.032 \pm 0.0005$ & 0.437 & 76.9 \\
& $\mathrm{R} 3$ & $0.095 \pm 0.012$ & $0.034 \pm 0.0045$ & 0.427 & 69.3 \\
\hline
\end{tabular}

${ }^{\text {a }}$ Results calculated according to VS fed to STRs

$\mathrm{N}=2-3$ 


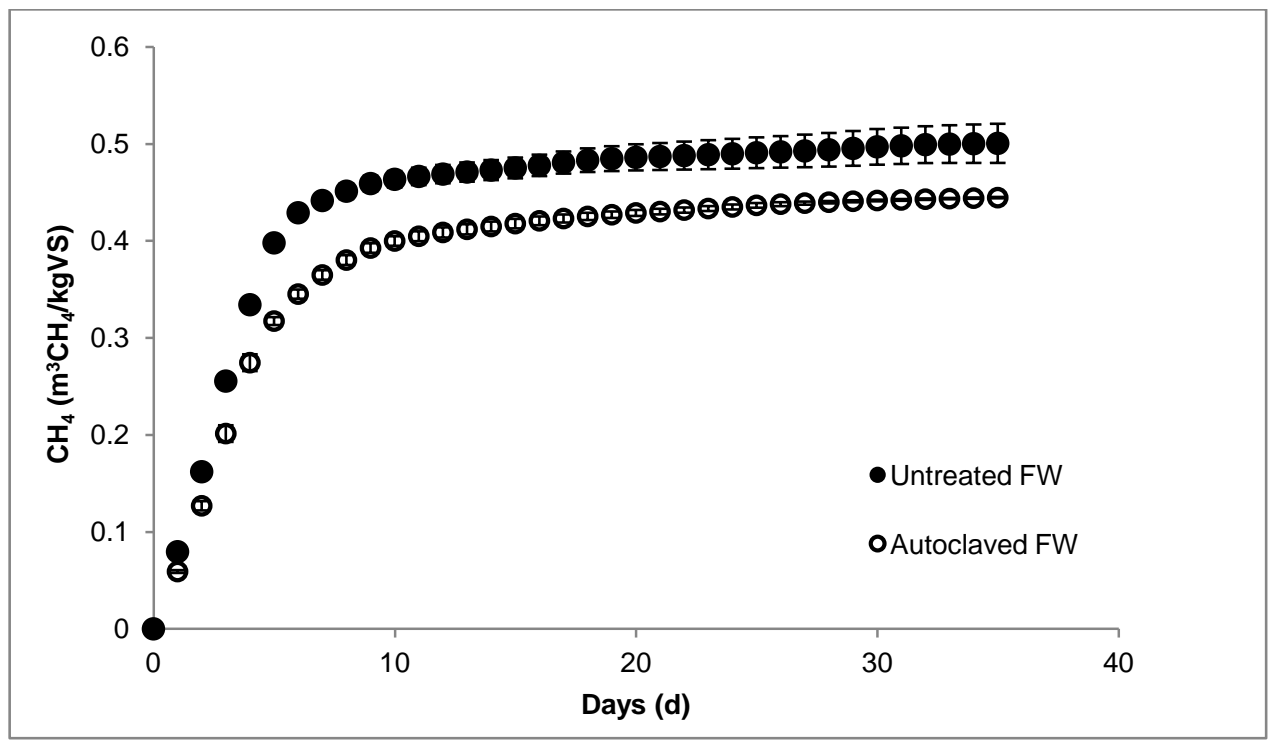

Fig. 1. Biochemical methane potential (BMP) and standard deviation of untreated and autoclaved food waste (FW) in 35-day assays. 


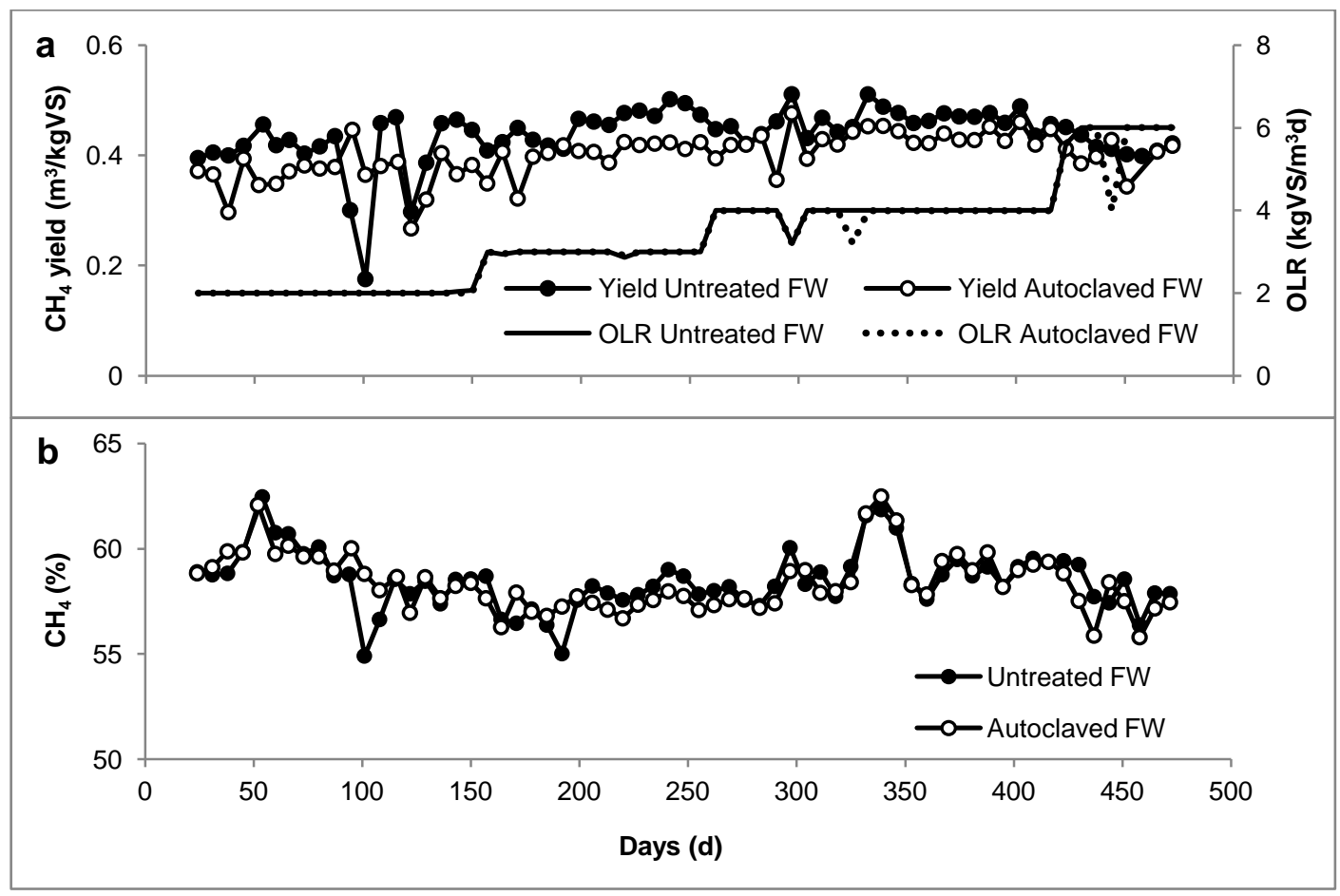

Fig. 2. Methane yields and contents in reactors treating untreated food waste (FW) and autoclaved FW during the semi-continuous operation. 


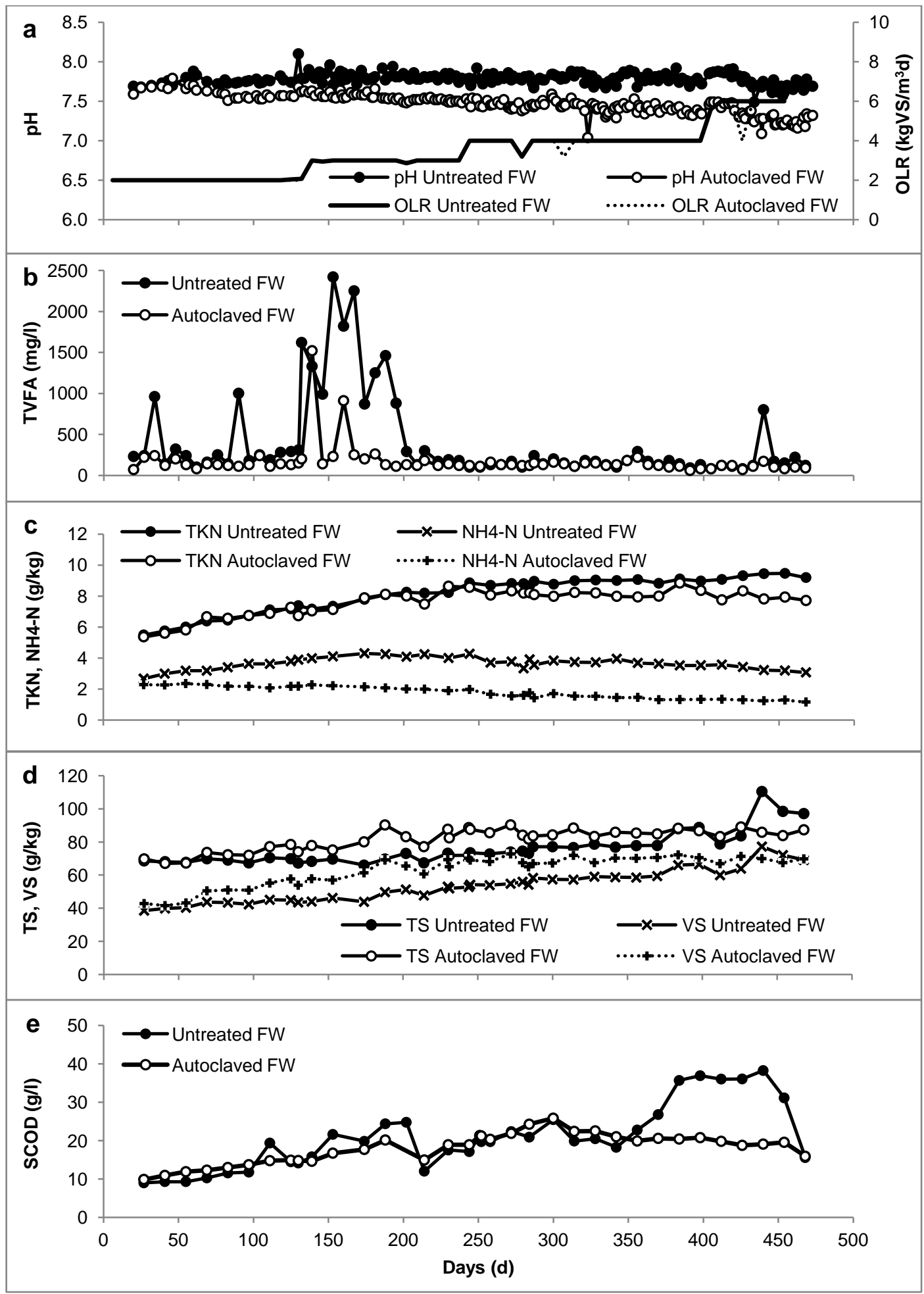

Fig. 3. Chemical characteristics ( $\mathrm{pH}, \mathrm{TVFA}, \mathrm{TKN}, \mathrm{NH}_{4}-\mathrm{N}, \mathrm{TS}, \mathrm{VS}, \mathrm{SCOD}$ ) of untreated food waste (FW) and autoclaved FW reactor contents during the semicontinuous operation. 


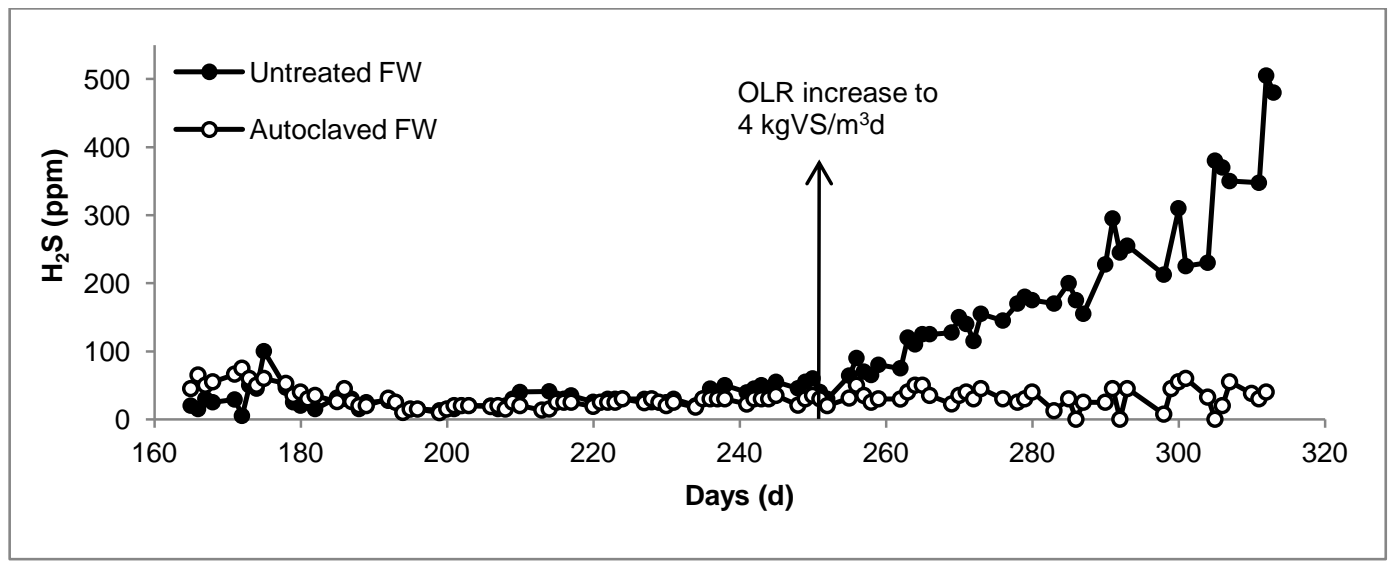

Fig. 4. $\mathrm{H}_{2} \mathrm{~S}$ contents in reactors treating untreated food waste $(\mathrm{FW})$ and autoclaved $\mathrm{FW}$ during days 166-314. 